\title{
Breeding Biology of Chakoor partridge (Alectoris chukar) in Bajaur, Khyber- Pakhtunkhwa, Pakistan: Critically affected by eggs collection and predation
}

\author{
Rahmat Ullah Khan ${ }^{1}$ and Karim Gabol ${ }^{1 *}$ \\ 1. Department of Zoology, University of Karachi, Karachi-75270 Pakistan \\ *Corresponding author's email: kgabol.gabol@gmail.com \\ Citation \\ Rahmat Ullah Khan and Karim Gabol. Breeding Biology of Chakoor partridge (Alectoris chukar) in Bajaur, Khyber- \\ Pakhtunkhwa, Pakistan: Critically affected by eggs collection and predation. Pure and Applied Biology. Vol. 10, Issue \\ 3, pp913-921. http://dx.doi.org/10.19045/bspab.2021.100094
}

\begin{tabular}{llll}
\hline \hline Received: $27 / 10 / 2020$ & Revised: $18 / 11 / 2020$ & Accepted: 019/12/2020 & Online First: 30/12/2020 \\
\hline
\end{tabular}

\section{Abstract}

The purpose of the study was to explore the main barriers responsible for the breeding success of chakoor partridge in four different mountainous locations of Bajaur during breeding seasons 2018 and 2019 respectively. This research work will enhance protection for the future progeny and grants beauty to the environment. Scientifically this is the first contribution in which a total of nineteen nests were explored with the help of a systematic survey and local shepherds. Data about breeding biology, nest characterization, and destructive factors recorded. The average clutch size $12.86 \pm 1.3$ eggs and incubation 24.04 \pm 0.6 days of $(n=238)$. While 6 nests consisting of 75 eggs were destroyed by egg collection and predation. The overall hatching success was (69\%). The egg's look was oblong with a smooth texture. The average weight of eggs $18.35 \pm 0.6(\mathrm{~g})$ and length $3.28 \pm 0.07(\mathrm{~cm})$ with diameter $3.08 \pm 0.07\left(\mathrm{~cm}^{2}\right)$. The look of nests was partial round, which was constructed from local dry grasses Fimbristylis squarrosa 60\%, Cynodon dactylon, Desmostachya bipinnata, Dichanthium annulatum 35\%, and feathers along with undifferentiated materials $5 \%$. Similarly the average nests diameter $26.42 \pm 3.3\left(\mathrm{~cm}^{2}\right)$, cup diameter $24.12 \pm 3.2\left(\mathrm{~cm}^{2}\right)$ and cup depth $6.19 \pm 0.4(\mathrm{~cm})$. This study concluded that chakoor perform their breeding activity from May to August in the mountainous habitat however, in absence of eggs collection, nest destruction, and predation, the breeding success will be more secure. We recommend that to generate awareness in public about this valuable bird and the implementation of regulations is required on a prior basis.

Keywords: Bajaur; Breeding biology; Chakoor partridge; Egg collection; Nest predation

\section{Introduction}

In district Bajaur, the Chakoor partridge are known as "Zaurk" and "Zaurka" for male and female respectively due to its luminous yellow eyes color. While in Turkish this partridge is recognized as "Kinali" because of its red color legs and beak [1]. The current research proposes an explanation of breeding biology and the main factors affecting the breeding of chakoor. Comparatively very low data about breeding biology are present especially in Pakistan because of difficulty to explore their nest. Chakoor partridge's basic ecology, reproductive biology, and behavior 
were studied in America by Galbreathe [2] and in Navada Christensen [3]. Various researches have been conducted on different aspects of chakoor, but very little information is present about their breeding ecology. So possible results obtained are more time consuming and striving in mountainous habitat because they make their nests in hideous and incredible places $[4,2]$.

The origin of chakoor partridge is hilly and mountainous areas that are famous for game purposes [5], which belongs to order Galliformes and family Phasianidae [6-8]. Generally, the sexes have similar morphology, but the male is somewhat larger with a spur on their legs. Chakoor partridge is a medium physique bird i.e. the male is about 510 to $800 \mathrm{~g}$ and the female has 450 to 680 gm $[1,9,10]$.

Chakoor partridge selects the habitats which satisfy the basic necessities of life definitely, like required food and secure nesting habitat $[11,12]$. Amongst all resources presence of water is the initial and very vital part of habitat in the mountainous and hilly areas for chakoor [13].

Chakoor partridge wants reproductive partners, female and male that coupling reproductively in April a male complete all their breeding behaviors [10]. Once the environmental conditions are unfavorable only a few couples perform breeding. The male chakoor takes away the female partner, to far away from the access of other males. Couples start calling and perform a "tide betting habit" kicking on the ground and pecking at various small things. The common kecking calls were a slow check, check, check made by both partners that slowly converts to chikor chikor, that can easily be heard from more distance $[6,10,14]$.

Basically, chakoor partridge laying once per annum but mostly depend on environmental conditions. Impregnates take place during early April to late July, clutch size per breeding, ranging from 5 to 23 , usual hatching duration is about 23-24 days [4]. The status of the chakoor is regular residents breeding habitat is not regular, the nest site location, and the number of offspring not regular [15]. Nestling able to fly at the age of fewer than twenty-one days [16]. Chicks are commonly not differentiated from their adult birds when they attain the age of 5 months. Mostly the chicks live in groups. They perform the basic activity in the form of groups too, like resting in the shadow of rocks or any shrubbery and taking water during daytime routinely and more specifically when the ecological temperature is more than $37\left(\mathrm{C}^{\circ}\right)[17,18]$. In natural habitat sufficient study has not been conducted specifically on the breeding ecology of chakoor, because probable target recordings are so trying due to hiding nest location $[4,2]$. As a ground nester each time they are at risk. Common predators along with humans are mammals and avian predation [4].

The objectives of this study were to explore the basic pattern of breeding habit and to know the structure and the composition of the nest, breeding season, clutch size, incubation period, breeding success and to note the effect of predation on eggs and eggs collection on breeding success of chakoor in Bajaur Khyber-Pakhtunkhwa Pakistan.

\section{Materials and Methods Study area}

The present research was carried out in the mountainous range of district Bajaur $\left(34^{0} 41.250 \mathrm{~N}, 71^{0} 30.541 \mathrm{E}\right), 3000$ to $5500 \mathrm{ft}$. Four study sites were selected in different locations, Location-A (Mountainous stretch of Mamund N 34 $4^{\circ} 44-45$ E $071^{0} 27.198$ and elevation $4000 \mathrm{ft}$ ), Location-B (Gawado Mountain range N 34038-40, E 071 ${ }^{0} 20-24$ and elevation $4600 \mathrm{ft}$ ), Location-C (Samsay

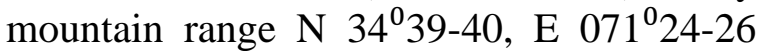
and elevation $4590 \mathrm{ft}$ ) and Location-D (Kooh-i-Moor N 340 39-41, E 071 ${ }^{0}$ 33-35 and elevation $5500 \mathrm{ft}$ ) (Fig. 1). 


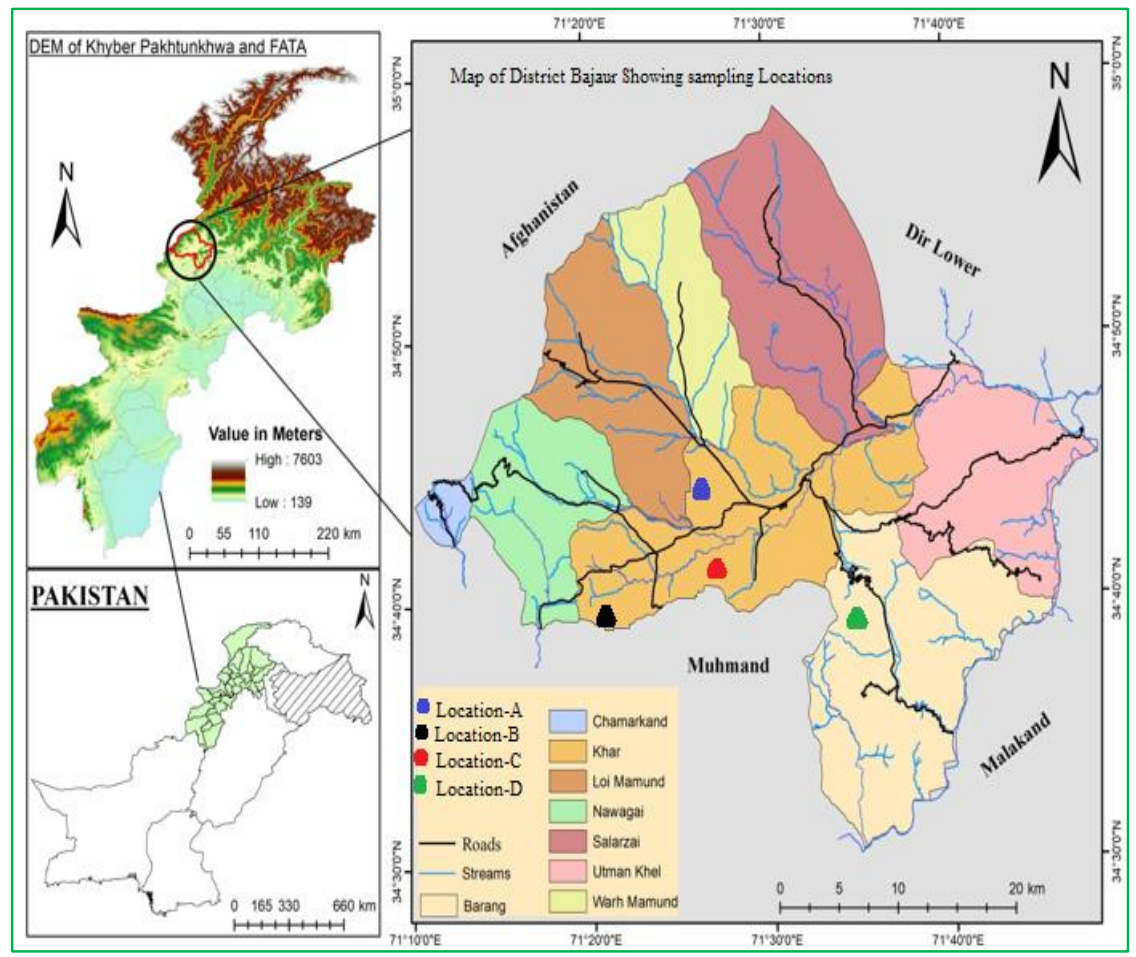

Figure 1. Map of study area district Bajaur valley, showing four studied locations

\section{Field work}

This research was conducted during breeding seasons (early April to late August) of the year 2018 and 2019 in possible habitat types of chakoor in four locations. In order to explore breeding birds and their nests in four locations, by two sampling methods i.e. random point count and systematic survey. Through both methods, targeted species nests were explored. Besides some nests were explored on behalf of local shepherds and hunters. All the targeted nests were allotted an identification number [7, 18-20]. The target nests were surveyed very carefully on a daily basis till the laying of the first egg, then after every two days until nest destruction, predation, or fledging noted (Fig. 2A). On each survey, all the relevant data regarding the number of eggs, constriction, destruction, eggs collection, and predation was recorded. Besides also noted each egg length, width, volume, texture, incubation period, hatching, and fledging success, nest shape, external and internal diameter, and cup depth as shown in (Table $1 \& 2$ ). During the whole collection period, [21] methods and guidelines were followed for utmost precaution and care.

Statistical analysis

Sample sizes varied for different parameters about breeding biology and nest characterization because we couldn't compare breeding variables for statistical significance due to the low sample size. However, analyzed as a mean \pm standard deviation by MS Excel (365).

Results

Chakoor partridge nests pointing out and breeding activities

As a whole 19 nests of chakoor partridge were studied in four different locations. In each Location; 7, 4, 5, and 3 nests were explored respectively. Among four targeted locations in the mountains, belts of locationA significantly higher number of nests $(36.84 \%)$ were explored followed by 
location-C (26.31\%), while location-D has the least number (15.78\%) of nests (Table 3 ). The exploration of Chakoor partridge nests is a very difficult task because they select their nest's site in unbelievable places. During laying the partridge cannot flash in or out of nests but use hide walking in bushes, and undoubtedly low population density. All the nests were explored in dense shrubbery, between rocks and caves covered by grasses. All nests were explored in the field survey from April to August 2018 and 19. Comparatively more nests were recorded during June (31.57\%) followed by May and July $(26.31 \%)$ respectively, while a very low number of nests $(15.78 \%)$ recorded during August, so these months reflect its breeding season (Table 1).

The breeding season of chakoor in Bajaur begins during May and lasts till August. During this period the chakoor was recorded in pairs of 2-5 (Fig. 2D). The pairing started from April to July, while the breeding duration May to August. The clutch size ranged from 8 to 16 eggs. Eggs collection by illegal hunters, shepherd, and predation were noted in all locations. In location-A and C (2) while in $\mathrm{B}$ and $\mathrm{D}$ (1) nest destruction noted respectively, with a total of 75 eggs, predated (25) and collected (50) (Table 3). The collected eggs are incubated and hatched by a laying hen in captivity and then the chicks use them for trade purposes (Fig. 2B). On a monthly basis, maximum nest destruction was recorded during June and July $(2,2)$ followed by May and August $(1,1)$ as shown in (Table 1).

\section{Chakoor partridge eggs sketch}

The color of eggs was Pale white with purplish spots, oblong look mostly with a smooth texture, the average weight of eggs was $18.35 \pm 0.6(\mathrm{gm})$. The average length $3.28 \pm 0.07(\mathrm{~cm})$ and the diameter $3.08 \pm 0.07$ (cm) (Table 2). The period of incubation ranged from 23-24 (24.04 \pm 0.6$)$ days. But hatching victory of $69.1 \%$ was so low because of egg collection and predation. However, the nestling left the nest very soon after hatching, so breeding success is equal to that of the hatching victory for this study (Table 3). Eggs collection and predation greatly affected the hatching success of chakoor. Hatching in location-A was $57.85 \%$, B $77.35 \%, \mathrm{C} 64.28 \%$ and D $76.92 \%$ recorded. All the eggs hatch within a few hours with open eyes and body covered contour feather nestling (Table 3).

\section{Nidology}

Nest constructed activities were not studied because they collect nest material by hiding walking in presence of any threat that does not show the exact location, however, they construct the nest out of find of other chakoor partridge according to local experts. But after complete breeding success, all the diametric measurements and materials of nests were analyzed. Basically, total nests were explored in dense grasses and bushes mostly between rocks covered by grasses in slopes (Fig. 2C). All the characteristics of nests were measured. Outlook of nests was almost partial round with mean outer diameter (26.42 \pm 3.3$)$, cup diameter $(24.12 \pm 3.2)$ and cup depth (6.19 \pm 0.4$)$. As ground nester the materials of nests were local grasses. The dominant grasses used as nest construction materials by mass was Fimbristylis squarrosa 60\%, Cynodon dactylon 5\%, Desmostachya bipinnata 15\%, Dichanthium annulatum 15\%, contour feathers 4\%, undifferentiated materials $1 \%$ (Table 4, Fig. $2 \mathrm{C} \& \mathrm{D})$. 

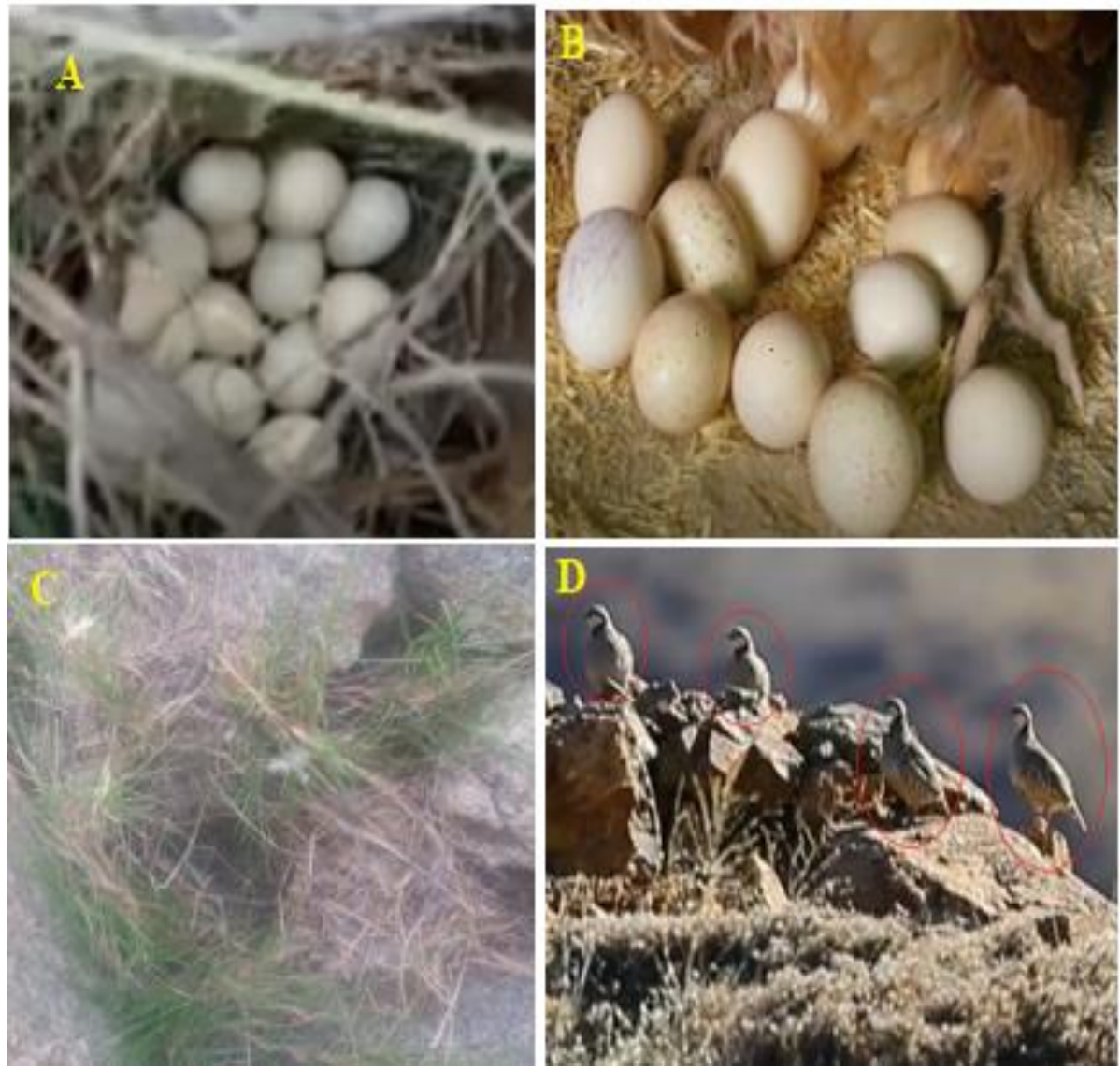

Figure 2. A) Chakoor nest consists of 15 eggs. B) Collected eggs beneath a lying hen for incubation C) Sketch of nest between rocks with cover of grasses D) Two pairs of parents chakoor

Table 1. Month wise detected nests of Chakoor partridge in each location along with coordinate gradient

\begin{tabular}{|c|c|c|c|c|c|c|c|}
\hline Sr. & May & June & July & August & Elevation (ft) & $\mathbf{N}$ & $\mathbf{E}$ \\
\hline L-A & 2 & 2 & 1 & 2 & 4095 & $34^{0} 44.371$ & $071^{0} 25.384$ \\
\hline L-B & 2 & 1 & 1 & - & 4185 & $34^{0} 39.168$ & $071^{0} 20.675$ \\
\hline L-C & - & 2 & 2 & 1 & 3663 & $34^{0} 40.544$ & $071^{0} 26.125$ \\
\hline L-D & 1 & 1 & 1 & - & 5985 & $34^{0} 39.270$ & $071^{0} 33.669$ \\
\hline $\begin{array}{c}\text { Total } \\
\text { Nests }\end{array}$ & 5 & 6 & 5 & 3 & & & \\
\hline $\begin{array}{c}\text { Percentage } \\
(\%)\end{array}$ & 26.31 & 31.57 & 26.31 & 15.78 & & & \\
\hline
\end{tabular}

"E” East Longitude, "ft" feet, "L" location, "N" North Latitude, "Sr", Serial number 
Table 2. Chakoor partridge (Alectoris chukar) eggs average morphometry in district Bajaur, (April-August) 2018 and 2019

\begin{tabular}{|c|c|c|c|c|c|}
\hline \multirow{2}{*}{ Eggs look } & Location-A & Location-B & Location-C & Location-D & \multirow{2}{*}{$\begin{array}{l}\text { Overall } \\
\text { M } \pm \text { std }\end{array}$} \\
\hline & Oblong & Oblong & Oblong & Oblong & \\
\hline Eggs color & $\begin{array}{c}\text { Pale white } \\
\text { with Purplish } \\
\text { spots }\end{array}$ & $\begin{array}{c}\text { Pale white } \\
\text { with Purplish } \\
\text { spots }\end{array}$ & $\begin{array}{l}\text { Pale white with } \\
\text { Purplish spots }\end{array}$ & $\begin{array}{c}\text { Pale white } \\
\text { with Purplish } \\
\text { spots }\end{array}$ & - \\
\hline Texture & Smooth & Smooth & $\mathrm{Sm}$ & Smooth & - \\
\hline Egg weight (gm) & $18.81 \pm 0.6$ & $17.55 \pm 0.4$ & $18.92 \pm 0.3$ & $18.14 \pm 1.2$ & $18.35 \pm 0.6$ \\
\hline Egg Length $(\mathrm{cm})$ & $3.12 \pm 0.04$ & $3 . .01 \pm 0.03$ & $3.17 \pm 0.04$ & $3.82 \pm 0.2$ & $3.28 \pm 0.07$ \\
\hline Egg diameter $\left(\mathrm{cm}^{2}\right)$ & $3.12 \pm 0.1$ & $3.06 \pm 0.07$ & $3.04 \pm 0.04$ & $3.1 \pm 0.08$ & $3.08 \pm 0.07$ \\
\hline
\end{tabular}

"cm" centimeter,"gm" gram, " $\mathrm{M} \pm$ std" Mean standard deviation

Table 3. Breeding design of Chakoor partridge (Alectoris chukar) in district Bajaur (April-August) 2018 and 2019 respectively

\begin{tabular}{|c|c|c|c|c|c|c|c|c|}
\hline Sr. & $\boldsymbol{\Theta}(\%)$ & $\begin{array}{l}\text { (\% } \\
\boldsymbol{\Theta}\end{array}$ & Total $\odot$ & \multicolumn{2}{|c|}{ ๑ } & $\begin{array}{c}\text { Incubatio } \\
\mathbf{n}\end{array}$ & clutch Size & $\begin{array}{c}\text { Hatching } \\
\text { success (\%) }\end{array}$ \\
\hline \multicolumn{8}{|c|}{ PR } \\
\hline L-A & $7(36.84)$ & 2 & 84 & 13 & 14 & $23.71 \pm 0.6$ & $12 \pm 1.7$ & 57.85 \\
\hline L-B & $4(21.05)$ & 1 & 53 & - & 12 & $24 \pm 0.7$ & $13.25 \pm 0.8$ & 77.35 \\
\hline L-C & $5(26.31)$ & 2 & 56 & 12 & 8 & $24.66 \pm 0.4$ & $11.20 \pm 2$ & 64.28 \\
\hline L-D & $3(15.78)$ & 1 & 45 & - & 16 & $23.80 \pm 0.7$ & $15 \pm 0.08$ & 76.92 \\
\hline Total/Avg & 19 & 6 & 238 & \multicolumn{2}{|c|}{75} & $24.04 \pm 0.6$ & $12.52 \pm 1.3$ & $69.1 \pm 8.3$ \\
\hline
\end{tabular}

“Avg” average, “回” destructed, "PR" eggs predation, "Cl” eggs collection “ $\bigcirc ”$ eggs, "L” locations A, B, C and “ \pm " Mean standard deviation, “ $\Theta$ " nest, “\%” percentage "Sr" Serial number

Table 4. Chakoor partridge (Alectoris chukar) nests characteristics in district Bajaur, (AprilAugust) 2018 and 2019

\begin{tabular}{|c|c|c|c|c|c|}
\hline \multirow{2}{*}{ Nest look } & Location-A & Location-B & Location-C & Location-D & Total \\
\hline & Partial round & Partial round & Partial round & Partial round & - \\
\hline $\begin{array}{l}\text { Average nest } \\
\text { diameter }\left(\mathrm{cm}^{2}\right)\end{array}$ & $27.28 \pm 2.7$ & $25.55 \pm 4.2$ & $26.54 \pm 2.5$ & $26.33 \pm 3.8$ & $26.42 \pm 3.3$ \\
\hline Cup diameter $\left(\mathrm{cm}^{2}\right)$ & $24.85 \pm 2.5$ & $23.5 \pm 4.2$ & $23.85 \pm 2.6$ & $24.3 \pm 3.7$ & $24.12 \pm 3.2$ \\
\hline $\begin{array}{l}\text { Average cup depth } \\
(\mathrm{cm})\end{array}$ & $6 \pm 0.7$ & $6.4 \pm 0.3$ & $5.96 \pm 0.5$ & $6.43 \pm 0.4$ & $6.19 \pm 0.4$ \\
\hline \multirow{6}{*}{ Nest Materials (\%) } & \multicolumn{5}{|c|}{ Fimbristylis squarrosa } \\
\hline & \multicolumn{5}{|c|}{ Cynodon dactylon } \\
\hline & \multicolumn{3}{|c|}{ Desmostachya bipinnata } & $15 \%$ & \\
\hline & \multicolumn{3}{|c|}{ Dichanthium annulatum } & $15 \%$ & \\
\hline & \multicolumn{3}{|c|}{ Feathers } & $4 \%$ & \\
\hline & \multicolumn{3}{|c|}{ Undifferentiated Materials } & $1 \%$ & \\
\hline
\end{tabular}

\section{Discussion}

The present results illustrate that the breeding of chakoor partridge (Alectoris chukar) is mainly affected by egg collection and predation $(31.51 \%)$. Some targeted nests were found empty before hatching so information about egg collection was reported from local shepherds and illegal hunters. While depredation was found as symbols of wild dogs, foxes, wild cats, and 
avian predators. According to a report on the nest's predators of common pheasants in Europe, the mammalian predators include European cats and avians consisting of common crows [8]. According to a report by Gaudioso [22] that chakoor breeding farms, egg collection, and human hunting decrease the opportunity of breeding in natural habitat. A similar study was conducted on nest predation of chakoor in Soth-Eastern Bulgaria by Gruychev [23] he noted (42.22 $\%$ ) nest destruction by egg predation.

Nests were noted in all four locations with unequal numbers. We studied 19 nests in the study area, because of very low breeding pairs and most threats in the study area. According to the study of Khan [7], chakoor are present in all possible mountainous habitats but the population density of chakoor is greatly affected by illegal hunting, predation, and egg collection in Bajaur. Also in Europe, the population is so low that in the future it will decrease up to $30 \%$ [24]. IUCN has placed chakoor as the least concern [25]. McGowan and Kirwan [26] reported the population of chakoor in Lebanon has declined.

All the nests were recorded during the breeding season (May-August) on mountainous slopes on the ground between rocks surrounded by dense grasses with elevation ranging from 3663-5985 (ft). The clutch size ranged from 7-18 eggs and the average incubation duration was 24 days. According to Perrins [10], chakoor perform their breeding activity during April that a courtship displays by a male. Similarly, by Christensen [4] chakoor attempted to breed during favorable environmental conditions from mid-April to late-July, clutch size ranged 6-21 eggs laid per hen in each season, while hatched after 24 days. Our result is also similar to that of Awan [17].

All the relevant average measurements of chakoor partridge eggs recorded in (Table 3). The look of eggs was oblong, color pale white with purplish spots and the texture smooth while in some nests with somewhat rough. Similar results were also reported by [27-29].

We recorded the average egg weight $(18.35 \pm 0.6 \mathrm{~g})$ of $(\mathrm{n}=238)$. According to the result of Cetin [30] the average weight of chakoor eggs 19.31, Song [16]. (19.16 g), and Ribeiro [29]. Approximately recorded similar results $(18.2 \pm 1.3)$. The aged hen laying heavier eggs as compared to the young one and the eggs laid at last are also heavier [29].

The average length of eggs was $32.8 \pm 0.07$ $(\mathrm{mm})$ and diameter $30.8 \pm 0.07\left(\mathrm{~mm}^{2}\right)$. Mourao [24], Ribeiro [29] reported the length of eggs $31.97 \pm 1.54\left(\mathrm{~mm}^{2}\right)$.

The average breeding success was not fully but $(69 \%)$ recorded. Because threats for nest destruction were more. Mahmood [31] reported average breeding success $(85 \%)$ in district lower Dir. Similarly, our results match the report of Awan [17], Roberts [32], Christensen [4] and Madge [33]. According to Richardson [34] gopher snake (Pituophis catenifer catenifer) devouring six chakoor eggs in Nevada.

After lifting the nest all the related morphometry and materials of nests were analyzed. All the nests were round to partial round in shapes. The average diameter $\left(\mathrm{cm}^{2}\right)$ of the nest $(n=19)(26.42 \pm 3.3)$ with cup diameter (24.12 \pm 3.2$)$ and cup depth (6.19 \pm 0.4$)$. According to Ollivier [26] Roberts [32] Mahmood [31], chakoor makes their nests beneath the rocks in dense vegetation in a small depression on the ground with a diameter ranging from 21-30.5 $\left(\mathrm{cm}^{2}\right)$.

The nest was constructed from various local grasses (95\%) and feathers along with some unknown materials $(5 \%)$. The most common grass species used for nest construction was Fimbristylis squarrosa (60\%). Del Hoyo [6] Christensen [4] and Mahmood [31] reported chakoor constructs their nests from dry 
grasses, the vegetation of Dodonaea viscosa, Poa annua, downy feathers, and few twigs on sloping locations.

In all four locations of district Bajaur possible habitat for the breeding of chakoor was present. But unfortunately, local shepherds, hunter ignorance activity, and habitat loss are involved to decrease the breeding success of chakoor. We recommend that to influence the awareness in local hunters and shepherds about the importance of chakoor and other wildlife that eggs collection, threatening and habitat destruction leads to finish off the pretty and precious bird locally. So we will improve the breeding success of chakoor to enhance and protect their habitat by improving awareness in locals. This investigation is helpful for the protection of chakoor breeding success in district Bajaur.

\section{Conclusion}

This study concluded that the breeding activities of chakoor begins from April and lasts until August in the mountainous territories of Bajaur valley. All possible habitats for breeding purposes are available, however, in absence of eggs collection, nest destruction, and predation, the breeding success will be more secure. But unfortunately breeding success and productivity are not fully because of more threats. Measurable protection are needed for the preservation of future progeny of chakoor partridge.

\section{Authors' contributions}

Conceived and designed the experiments: K Gabol, Performed the experiments: RU Khan, Analyzed the data: RU Khan, Contributed materials/ analysis/ tools: K Gabol, Wrote the paper: RU Khan.

\section{Acknowledgements}

The authors acknowledge University of Karachi \& locals of the study areas.

\section{References}

1. Ullah S Higgins H Braem B Latre B Blondia C Moerman I \& Kwak KS (2012). A comprehensive survey of wireless body area networks. J Med Syst 36(3): 1065-1094.
2. Galbreath D S \& Moreland R (1953). The Chukar partridge in Washington Biological Bulletin 11, Washington State Game Department, pp. 54.

3. Christensen GC (1954). The Chukar partridge in Nevada. Nevada Fish and Game Commission. Rept Biol Bulletin 1: 329-341.

4. Christensen GC (1996). Chukar (Alectoris chukar) in the Birds of North America, No. 258 (Poole A \& Gill F eds). The Academy of Natural Sciences, Philadelphia. The American Ornithologists Union, Washington, D.C.

5. Mourao JL Barbosa AC Outor MD \& Pinheiro VM (2010). Age affects the laying performance and egg hatchability of redlegged partridges (Alectoris rufa) in captivity. Poult Sci 89(11): 2494-2498.

6. Del Hoyo JD Elliott A \& Bierregaard R (1994). New World vultures to Guineafowl: Barcelona: Lynx 2.

7. Khan RU Sadam A \& Mahmood S (2020). Population Ecology of Chakor Partridge (Alectoris chukar) in District Bajaur, Khyber Pakhtunkhwa, Pakistan. Pak J Zool 1-4.

8. Shahabuddin Saeed K Akhtar N Khan A Akhtar E \& Akhtar B (2016). Exploring the Population Status of Family Phasianidae in Totalai Game Reserve, District Buner, and Khyber Pukhtunkhwa, Pakistan. Brit J Poul Sci 5(1): 13-20.

9. Ahmad B Nabi G Hayat M \& Muhammad J (2017). Habitat study of Chukar partridge (Alectoris chukar) in district Malakand: A case study of town Thana, Pakistan. $J$ of Biodiver and Environ Sci (JBES) 11(4).

10. Perrins C (2003). Firefly encyclopedia of birds. Firefly Books Limited, Buffalo, New York, USA.

11. Manly B Donald MC Thomas LD \& Erickson WP (2007). Resource selection by animals: statistical design and analysis for field studies: Springer Sci \& Bus Media.

12. Nature I (2003). IUCN Red list of threatened species: Species Survival Commission Gland, Switzerland IUCN.

13. Leopold A (1933). Game management. Charles Scribner's Sons, New York, pp 481.

14. Yalmaz A \& Tepeli C (2007). The native partridges of Turkey. Int J Gall Con 1: 9-11. 
15. Ehrlich P Dobkin D \& Wheye D (1988). The Birders Handbook: A Field Guide to the Natural History of North American Birds. New York: Simon and Schuster, Inc.

16. Song KT Choi SH \& Oh HR (2000). A comparison of egg quality of pheasant, chukar, quail and guinea fowl. Asi-Aust $J$ Ani Sci 13(7): 986-990.

17. Awan MN Saleem MM Awan MS \& Basharat K (2006). Distribution, Status and Habitat Utilization of Chukar (Alectoris chukar) in Machiara National Park district Muzaffarabad Azad Kashmir. J of Agric and Social Sci.

18. Battisti C Vignoli L \& Bologna MA (2010). Breeding birds in an Appennine Massif (Majella, central Italy): do "common species" could act as surrogate for characterize species richness and composition of the communities. Ekológia (Bratislava) 29(2): 207-218.

19. Bibby CJ Burgess D Hill DA (1992). Bird census techniques. Academic Press, London, pp. 287.

20. Sutherland WJ (2006). Ecological census techniques, II edition, Cambridge University Press, Cambridge, pp. 336.

21. Chesness RA Nelson MM Longley WH (1968). The Effect of Predator Removal on Pheasant Reproductive Success. The $J$ Wildlife Manag 32(4): 683-697.

22. Gaudioso VR Alonso ME Robles R Garrido JA \& Olmedo JA (2002). Effects of housing type and breeding system on the reproductive capacity of the red-legged partridge (Alectoris rufa). Poul Sci 81(2): 169-172.

23. Gruychev G (2012). Nest Predation of Chukar Partridge (Alectoris chukar Gray, 1830) In Southeastern Bulgaria: Experimental Study. Amélia Palma, Miguel Pestana, \& Anamaria Azevedo. Pine Resin 78.

24. Birdlife International (2015). European red list of birds.
25. Birdlife International (2016). The IUCN red list of threatened species.

26. McGowan PJK \& Kirwan GM (2016). In: Handbook of the birds of the world alive (eds. J del Hoyo A Elliott J Sargatal DA Christie \& Ede J). Lynx Edicions, Barcelona.

27. Hashemipour H Khaksar V \& Kermanshahi H (2011). Application of probiotic on egg production and egg quality of chukar partridge. Afri J Biot 10(82): 19244-19248.

28. Lindbloom A Reese K \& Zager P (2003). Nesting and Brood Rearing Characteristics of Chukars, in West Central Idaho. Western North Am Nat 63(4): 9-439.

29. Ribeiro S Pereira AF Capela E Silva F \& Ferraz de Oliveira MI (2013). Physical characteristics of the eggs of red-legged partridge (Alectoris rufa) reared in captivity. Arquivo Brasil Med Vet Zool 65(6): 1904-1908.

30. Cetin O Kirikci K \& Gulșen N (1997). Some productivity characteristics of Chukar partridges (Alectoris chukar) in different management conditions. J of Vet Sci 13(2): 5-10.

31. Mahmood T Ahmad I Akrim F Hamid A Waseem M Hussain A \& Nadeem MS (2019). Breeding Ecology of Chukor Partridge (Alectoris chukar) in Lower Dir District, Khyber Pakhtunkhwa, Pakistan. Pak J Zool 51(1): 265-271.

32. Roberts TJ (1991). The Birds of Pakistan, Volume 1: Regional Studies and Nonpasserines: Oxford University Press, Karachi, Pakistan.

33. Madge S McGowan PJ \& Kirwan GM (2002). Pheasants, partridges and grouse: a guide to the pheasants, partridges, quails, grouse, guineafowl, buttonquails and sandgrouse of the world: A and C Black.

34. Rearden JD (1951). Identification of waterfowl nest predators. The $J$ Wild Managt 15(4): 386-395. 